International Journal of Engineering \& Technology, $7(3.31)(2018) 219-223$
International Journal of Engineering \& Technology
WPC
Website www.sciencepubco.com/index.php/IJET
Research paper

\title{
Study of Mechanical Properties of Pervious Concrete as a Pavement Material by Partial Replacement of Ggbs in Cement with Addition of Cellulose Fibers
}

\author{
K. M. Ganesh ${ }^{1 *}$, A. S. S. Vara Prasad ${ }^{2}$, P. S. Viswa Harish ${ }^{2}$, A. Subrahmanyam Raju ${ }^{1}$ \\ ${ }^{1}$ Department of Civil Engineering, SRKR Engineering College, Bhimavaram, Andhra Pradesh, India-534204 \\ ${ }^{2}$ Department of Civil Engineering, Kakinada Institute of Technology and Science, Divili, Andhra Pradesh, India-533433 \\ *Corresponding author E-mail:lakshmimanojna.k@gmail.com
}

\begin{abstract}
Among all the transportation systems roadways is most commonly used transportation system. But in present scenario roads faces a lot of problems like potholes, cracks and many other distresses. Not even these but water is also the main enemy to the pavement which causes deformations and changes the texture of subgrade soil resulting in large variation in performance.

The total Impervious Surface Change (ISC) in India for the decade 2000 to 2010 is $2274.62 \mathrm{~km}^{2}$. This is one of the most considerable problems due to rapid urbanization where there is a tremendous increase in construction of black topped and different types of impervious pavements. This has an adverse effect on the environment as the storm water becomes stagnant over the surface of the pavement due to inadequate drainage conditions.

The necessity for reducing stagnation and the surface runoff has given the inception of pervious pavement surface. Pervious concrete pavement is a special type of its kind with high perviousness with no or minimal fines which allow water to percolate through it and thus the water which is accumulated over the surface can be collected and used for various purposes.

The present work studied the mechanical properties and also the permeability of pervious concrete of mix 3:1 aggregate cement ratio. The control mix is altered by partially replacing $30 \%$ of cement with Ground Granulated Blast furnace Slag (GGBS), included Cellulose fibers of $5 \%$ of weight of the cementitious material and combination of both in one mix and compared the results obtained.

The properties such as compressive strength, split tensile strength, flexural strength and permeability are assessed by performing tests. It was observed that there is an increase in Compressive Strength, Split Tensile Strength, Flexure Strength and decrease in the permeability in the altered pervious concrete mixes when compared to the Pervious concrete with no additives.
\end{abstract}

Keywords: Cellulose Fibers, Cement, GGBS, Pavement, Pervious Concrete

\section{Introduction}

Pervious or porous concrete is defined as "no-fines" concrete or open graded concrete which allows rain water to percolate to the sub-base through the pavement carriage way. The principal ingredients are quite similar to conventional concrete. It differs mainly from the conventional concrete in the percentage of void space within pervious concrete. The void spaces typically range between $15-25 \%$.

The most of the street roads are cement concrete roads which posses the strength more than they require as majority of the street roads carry considerably low volume. The black topped roads cannot be laid there as it requires more work space when compared to the cement concrete road and the cost of construction is high.

The yearly precipitation including snowfall in India is of the order of $4000 \mathrm{BCM}$ and replenishable ground water resources are only $433 \mathrm{BCM}$ which indicates a huge deficit and the necessity for reducing the difference between them.

The adequacy of the efficient management of storm water in an economical and environmental friendly manner is the frontline problem for all the planners, public works officials and developers.

\section{Objectives of the investigation}

Pervious concrete which is extensively used in non-pavements applications have only a limited use in pavement applications. The objectives of the current study are

- To develop the initial mix design to evaluate possible alternatives using various water-cement and aggregate-cement ratios.

- To investigate the properties of pervious concrete with GGBS, natural fibres like Cellulose and both.

- To conduct the necessary tests to assess the strength and permeability.

\section{Review of Literature}

Malhotra.V.M (1976) discussed about pervious concrete applications and properties. He concluded the pervious concrete compressive strength which is dependent on the aggregate-cement and the water-cement ratio[1].

Richard Menninger (1988) released results about the tests conducted on porous concrete. The experimental results give him an 
idea about the optimum water cement ratio and permeability which are vice versa function[2].

Vinson K. D and Sargaphuti.M, Shah S. P (1993) ascertained that one of the methods to minimize the adverse effects of shrinkage cracking is to reinforce concrete with discrete, randomly distributed fibers. The efficiency of cellulose fiber in arresting cracks was studied. A ring-type specimen was used for experimentation for a restrained shrinkage cracking test. The concrete was reinforced with six different types of fibers, with a fiber content of 0.5 percent by volume were tested. The concrete with cellulose fiber reinforcement showed an ability to reduce the crack width significantly as compared to unreinforced concrete. The concrete reinforced with 0.5 percent cellulose fibers showed excellent performance when compared to that of concrete with 0.5 polypropylene fibers. The long-term mechanical performance of polypropylene and cellulose fiber reinforced concrete was also evaluated[3].

Ghafoori Nader and S.Dutta (1995) conducted research on various aspects of pervious concrete extensively. This study includes the comparability of conventional concrete in the shrinkage and depth of water point of view.[4].

Paul Klieger (2003) performed experimental study on the effects on the strength and durability of conventional concrete. He concluded that the reduction in compressive strength of the pervious concrete with the presence of air decreases as the as the cement content decreases and the size of aggregate decreases[5]. Ammar A. Muttar (2013) inspected the mechanical properties of no-fines concrete with or without polypropylene fiber. Good compressive strength is achieved with an aggregate -cement ratio of $3: 1$ and $0.9 \mathrm{~kg} / \mathrm{m} 3$ polypropylene fibers[6].

Darshan Shah and Jayesh Kumar (2014) investigated on hardened properties of pervious concrete. They concluded that the pervious concrete has highest compressive strength of $12.71 \mathrm{~N} / \mathrm{mm}^{2}$ and highest flexural strength of $1.91 \mathrm{~N} / \mathrm{mm}^{2}[7]$.

Swaroop.A.H.L, Venkateswararao.K, Prof. Kodandaramarao.P (2013) investigated on durability aspects of Concrete with GGBS and Fly ash. The 20\% GGBS replacement gives a good durability results. When compared to weight loss GGBS offer more resistance than fly ash[8].

Vinayak Awasare, Prof. Nagendra.M.V (2014) carried out an experimental study on GGBS concrete. This study is concrete with $20 \%, 30 \%, 40 \%$ and $50 \%$ replacement of the cement with GGBS. The maximum strength is achieved at replacing $30 \%$ replacement of cement with GGBS[9].

Huda Nema Khalifa (2015) conducted experiments on the effect of adding fibre and crystal form cellulose in cconcrete. It may work as super plasticizer which reduces water absorption rate and influence the strength and the elasticity. The results are concluded for $14 \%$ for cellulose fiber and $6.5 \%$ cellulose crystal. The results indicated that the crystal improved the workability at $5 \%$ after 28 days curing period[10].

Selvaraj. R, Amirthavarshini. M (2016) carried out research on enhanced porous concrete and determined a method to quantify the permeability of pervious concrete. The size of coarse aggregate is big then the total void ratio is high. With th increase in coarse aggregate size the compressive and flexural strength of pervious concrete is lowered [11].

\section{Materials for Study}

\section{Concrete}

Concrete is a composite material in which the both fine aggregate and coarse aggregate are bonded together by the cement when mixed with water.

\section{Fiber Reinforcement in Concrete}

Fiber-reinforced concrete (FRC) is special concrete which contains uniformly distributed and randomly oriented short discontinuous fibrous material to increase its structural integrity.

\section{Ground Granulated Blast Furnace Slag}

GGBS is a by-product from the Limestone, Iron-ore, coke and iron manufacturing at a temperature of about $1500^{\circ} \mathrm{C}$ to $1600^{\circ} \mathrm{C}$.
The chemical composition is similar to Portland Cement. The molten slag after the tapping of the molten iron is waterquenched rapidly resulting in the formation of a glassy granulate which is further dried and ground to the required size.

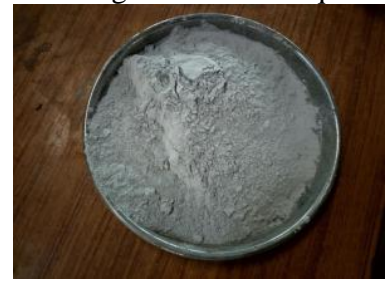

Fig 3.1.Ground Granulated Blast Furnace Slag

\section{Cellulose fiber}

Cellulose fiber is added to the concrete during batching. Small quantities of fiber in the mix may increase the cohesion and prevent sedimentation due to their interlocking network characteristics. The result may be that in some, but not all, cases the quantity of bleed water may be reduced

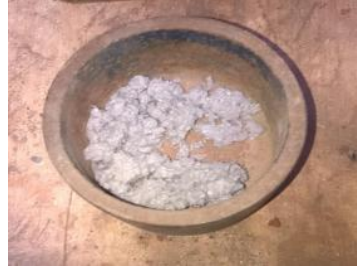

Fig 3.2 Cellulose fiber

Table 3.1 Properties of Cellulose fiber

\begin{tabular}{|c|c|}
\hline Property & $\mathbf{1 0 0 \%}$ virgin cellulose fiber \\
\hline Specific gravity & 1.1 \\
\hline Average fiber length & $2.1 \mathrm{~mm}$ \\
\hline Diameter & $0.016 \mathrm{~mm}$ \\
\hline Max. Moister & $85 \%$ by weight of fiber \\
\hline Fiber count & 1.44 billion \\
\hline Density & $1.1 \mathrm{gm} / \mathrm{cm} 3$ \\
\hline Surface area & $25000(\mathrm{~cm} / \mathrm{gm})$ \\
\hline Fiber tensile strength & $620-900 \mathrm{MPa}$ \\
\hline Fiber spacing in concrete & $480 \mu \mathrm{m}$ avg. \\
\hline Plastic crack resistance & $85.1 \%$ less than ordinary conc. \\
\hline
\end{tabular}

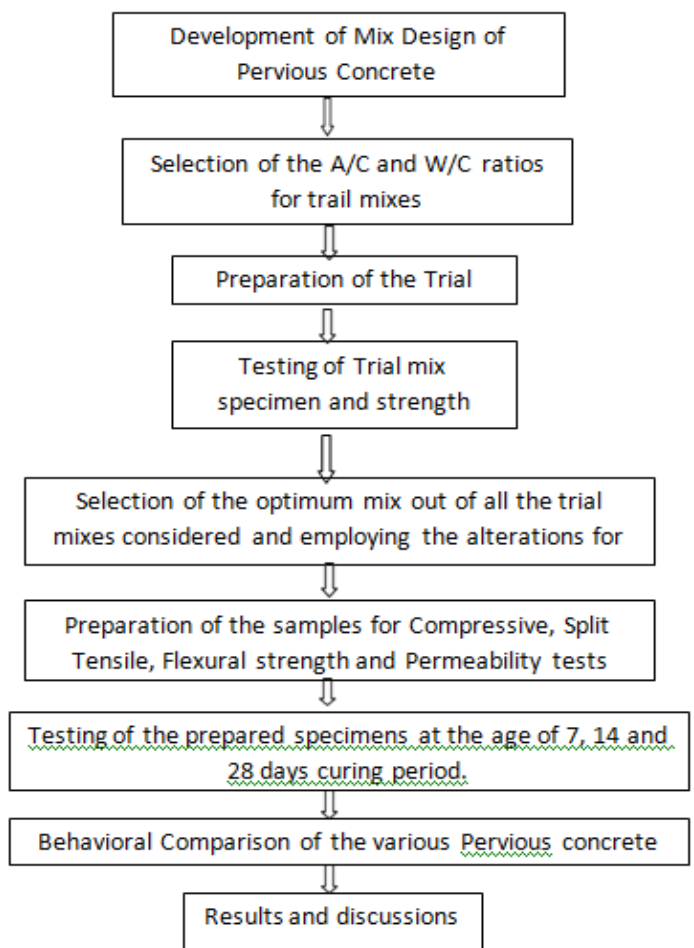

Flow chart of Methodology 


\section{Results and Discussions}

\subsection{General}

The experimental results are presented and discussed. The compressive strength, Split Tensile strength, permeability, flexural strength, Young's modulus test results are tabulated and the variation of mean strength is plotted against curing period in the following figures.

\subsection{Coefficient of Permeability}

The 28-day Coefficient of Permeability of various Pervious Concrete specimens were calculated using falling head method by using conventionally made permeability apparatus and the results were tabulated for in Table.4.1

Table 4.1 Coefficient of Permeability of various mixes

\begin{tabular}{|l|l|}
\hline Type of Mix & Permeability $(\mathbf{c m} / \mathbf{s e c})$ \\
\hline PC & 0.865 \\
\hline PC+CF & 0.824 \\
\hline PC+GGBS & 0.846 \\
\hline PC+CF+GGBS & 0.816 \\
\hline
\end{tabular}

\subsection{Modulus of Elasticity}

The 28- day Young's Modulus of various Pervious Concrete specimens were obtained and are shown in the below Table.4.2

Table 4.2 Modulus of Elasticity for various mixes

\begin{tabular}{|l|l|}
\hline Type of Mix & Permeability $(\mathbf{c m} / \mathbf{s e c})$ \\
\hline PC & 20.00 \\
\hline PC+CF & 20.34 \\
\hline PC+GGBS & 30.64 \\
\hline PC+CF+GGBS & 31.11 \\
\hline
\end{tabular}

\subsection{Comparison of Compressive Strength}

The Compressive strength of mixes with Cellulose fiber, GGBS and both GGBS and Cellulose fiber are tabulated in table4.3 and compared with that of the Pervious Concrete mix with no additives. The Fig.4.1 depicts the variation of the Compressive strength of various mixes with curing period

Table 4.3 Compressive Strength for various mixes with curing periods

\begin{tabular}{|c|c|c|c|c|}
\hline $\begin{array}{c}\text { Curing } \\
\text { Period } \\
\text { (Days) }\end{array}$ & $\begin{array}{c}\text { PC } \\
\text { MPa }\end{array}$ & $\begin{array}{c}\text { PC+CF } \\
\text { MPa }\end{array}$ & $\begin{array}{c}\text { PC+GGBS } \\
\text { MPa }\end{array}$ & $\begin{array}{c}\text { PC+CF+GGBS } \\
\text { MPa }\end{array}$ \\
\hline 7 & 12.33 & 13.563 & 14.432 & 14.16 \\
\hline 14 & 17.66 & 18.832 & 20.295 & 20.33 \\
\hline 28 & 24.695 & 25.66 & 26.279 & 27.66 \\
\hline
\end{tabular}

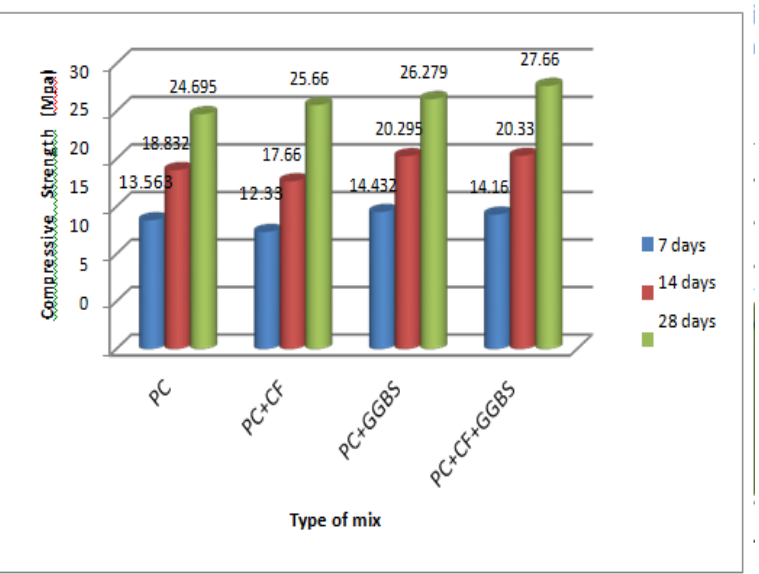

Fig 4.1 Comparison of Compressive Strength
From Fig.4.1, it was observed that there is an increase in Compressive strength of $10 \%$ in case of Pervious Concrete with Cellulose fiber, $17.04 \%$ in case of Pervious Concrete with GGBS and $14.18 \%$ in Pervious Concrete with both Cellulose fiber and GGBS respectively when compared to that of Pervious Concrete with no additives at 7 days curing period.

\subsection{Comparison of Split Tensile Strength}

The Split Tensile strength of mixes with Cellulose fiber, GGBS and both GGBS and Cellulose fiber are tabulated in table 4.4 and compared with that of the Pervious Concrete mix with no additives. Split Tensile strength of various mixes with curing period is shown in Table 4.4.

Table 4.4 Split Tensile Strength for various mixes with curing periods

\begin{tabular}{|c|c|c|c|c|}
\hline $\begin{array}{c}\text { Curing } \\
\text { Period } \\
\text { (Days) }\end{array}$ & $\begin{array}{c}\mathrm{PC} \\
\mathrm{MPa}\end{array}$ & $\begin{array}{c}\mathrm{PC}+\mathrm{CF} \\
\mathrm{MPa}\end{array}$ & $\begin{array}{c}\text { PC+GGBS } \\
\mathrm{MPa}\end{array}$ & $\begin{array}{c}\text { PC+CF+GGBS } \\
\mathrm{MPa}\end{array}$ \\
\hline 7 & 1.69 & 1.84 & 1.98 & 1.98 \\
\hline 14 & 2.19 & 2.26 & 2.33 & 2.61 \\
\hline 28 & 2.68 & 2.78 & 2.83 & 3.11 \\
\hline
\end{tabular}

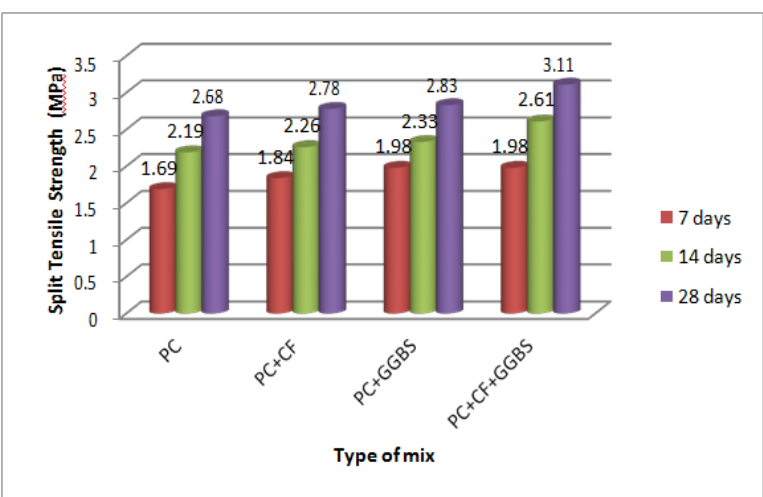

Fig 4.2 Comparison of Split Tensile Strength

From Fig.4.2, it was identified that there is an increase in Split Tensile strength of $8.87 \%$ in case of Pervious Concrete with Cellulose fiber, $17.15 \%$ in case of Pervious Concrete with GGBS and $17.15 \%$ in case of Pervious Concrete with both Cellulose fiber and GGBS respectively when compared to that of Pervious Concrete with no additives at 28 days curing period.

\subsection{Comparison of Coefficient of permeability}

The Coefficient of permeability of Pervious Concrete with Cellulose fiber, Pervious Concrete with GGBS and Pervious Concrete with both GGBS and Cellulose fiber has been tabulated in table 4.5 and compared with that of the Pervious Concrete with no additives. The Fig.4.3 depicts the variation of the Coefficient of permeability of various mixes with 28 day curing period.

Table 4.5 Coefficient of permeability for various mixes with curing periods

\begin{tabular}{|c|c|c|c|c|}
\hline $\begin{array}{c}\text { Curing } \\
\text { Period } \\
\text { (Days) }\end{array}$ & $\begin{array}{c}\mathrm{PC} \\
\mathrm{MPa}\end{array}$ & $\begin{array}{c}\mathrm{PC}+\mathrm{CF} \\
\mathrm{MPa}\end{array}$ & $\begin{array}{c}\text { PC+GGBS } \\
\mathrm{MPa}\end{array}$ & $\begin{array}{c}\mathrm{PC}+\mathrm{CF}+\mathrm{GGBS} \\
\mathrm{MPa}\end{array}$ \\
\hline 28 & 0.865 & 0.824 & 0.846 & 0.816 \\
\hline
\end{tabular}




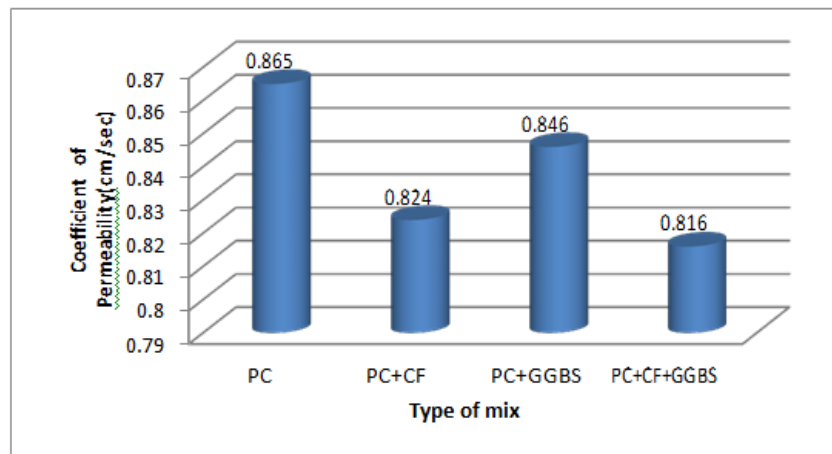

Fig 4.3 Comparison of Coefficient of Permeability

From Fig.4.3, it was observed that there is a decrease in Coefficient of Permeability of $4.73 \%$ in case of Pervious Concrete with Cellulose fiber, $2.19 \%$ in case of Pervious Concrete with GGBS and $5.66 \%$ in case of Pervious Concrete with both Cellulose fiber and GGBS respectively when compared to that of Pervious Concrete with no additives at 28 days curing period

\subsection{Comparison of Flexural Strength}

The Flexural strength of mixes with Cellulose fiber, GGBS and both GGBS and Cellulose fiber are tabulated in table.4.6 and compared with that of the Pervious Concrete mix with no additives. The Fig.4.4 depicts the variation of the Flexural strength of various mixes with curing period

Table 4.6 Flexural Strength for various mixes with curing periods

\begin{tabular}{|c|c|c|c|c|}
\hline $\begin{array}{l}\text { Curing } \\
\text { Period } \\
\text { (Days) }\end{array}$ & $\begin{array}{c}\mathrm{PC} \\
\mathrm{MPa}\end{array}$ & $\begin{array}{c}\mathrm{PC}+\mathrm{CF} \\
\mathrm{MPa}\end{array}$ & $\begin{array}{c}\text { PC+GGBS } \\
\mathrm{MPa}\end{array}$ & $\begin{array}{c}\text { PC+CF+GGBS } \\
\mathrm{MPa}\end{array}$ \\
\hline 7 & 2.67 & 2.68 & 3.924 & 4.43 \\
\hline 14 & 3.02 & 2.943 & 4.31 & 5.33 \\
\hline 28 & 3.88 & 3.924 & 5.02 & 6 \\
\hline
\end{tabular}

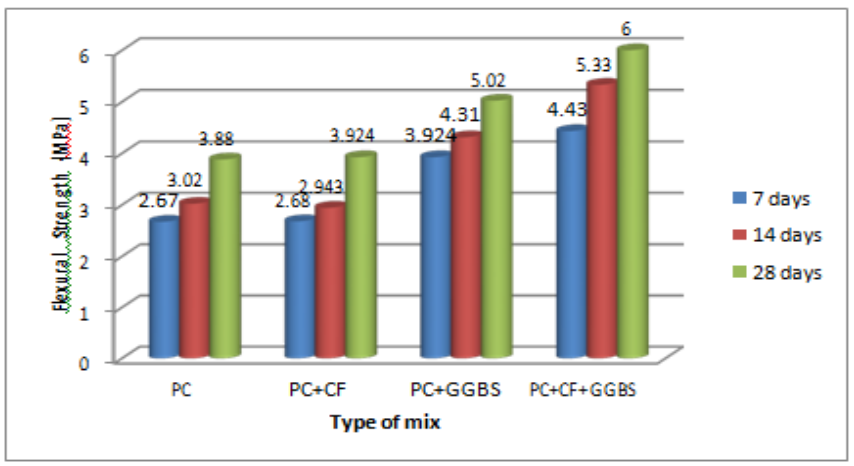

Fig 4.4 Comparison of Flexural Strength

From Fig.4.4, it was observed that there is no significant change in the Pervious Concrete Flexural strength with addition of Cellulose Fibers when compared to that of the Pervious Concrete with no additives at 7 days curing period. It was observed that there is an increase in Flexural Strength of $46.97 \%$ in case of Pervious Concrete with GGBS and $65.01 \%$ in case of Pervious Concrete with both Cellulose fiber and GGBS respectively when compared to that of Pervious Concrete with no additives at 7 days curing period.

\subsection{Comparison of Modulus of Elasticity}

The Modulus of Elasticity of Pervious Concrete with Cellulose fiber, Pervious Concrete with GGBS and Pervious Concrete with both GGBS and Cellulose fiber are tabulated in table.4.7 and compared with Pervious Concrete with no additives. The Fig.4.5 depicts the variation of the Modulus of Elasticity of various mixes with curing period
Table 4.7 Modulus of Elasticity for various mixes with curing periods

\begin{tabular}{|c|c|c|c|c|}
\hline $\begin{array}{c}\text { Curing } \\
\text { Period } \\
\text { (Days) }\end{array}$ & $\begin{array}{c}\mathrm{PC} \\
\mathrm{MPa}\end{array}$ & $\begin{array}{c}\mathrm{PC}+\mathrm{CF} \\
\mathrm{MPa}\end{array}$ & $\begin{array}{c}\text { PC+GGBS } \\
\mathrm{MPa}\end{array}$ & $\begin{array}{c}\text { PC+CF+GGBS } \\
\mathrm{MPa}\end{array}$ \\
\hline 28 & 20.000 & 20.347 & 30.666 & 31.111 \\
\hline
\end{tabular}

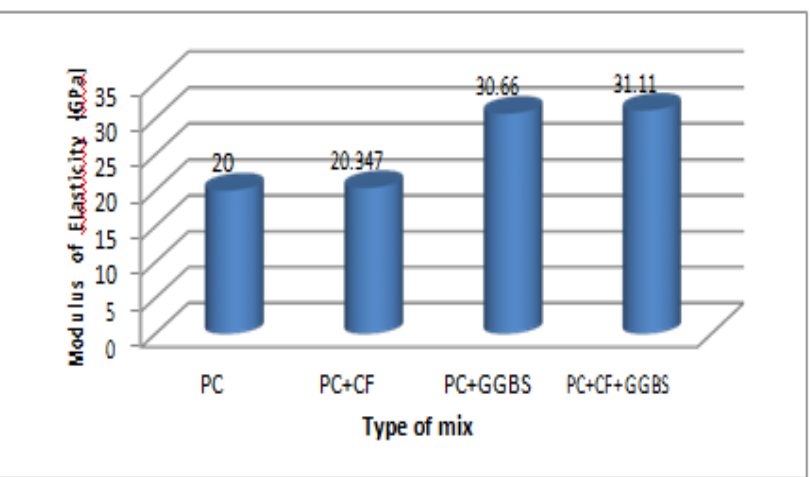

Fig 4.5 Comparison of Modulus of Elasticity

From Fig.4.5, it was observed that there is an increase in Modulus of Elasticity of $1.7 \%$ in case of Pervious Concrete with Cellulose fiber, $53.33 \%$ in case of Pervious Concrete with GGBS and $55.55 \%$ in case of Pervious Concrete with both Cellulose fiber and GGBS respectively when compared to that of Pervious Concrete with no additives at 28 days curing period.

\section{Conclusion}

From the present study the following conclusions are identified:

- The trial mix with Cement-aggregate ratio 1:3 and with water-cement ratio of 0.3 is observed to be the mix with highest strength of all the considered 12 trial mixes.

- For Compressive strength, it was observed that there was an increment of $3.90 \%$ in case of Pervious Concrete with Cellulose fiber, $6.41 \%$ in case of Pervious Concrete with GGBS and $12 \%$ in Pervious Concrete with both Cellulose fiber and GGBS when compared to that of Pervious Concrete with no additives at 28 days curing period

- For Split Tensile strength, it was observed that there was an increment $3.73 \%$ in case of Pervious Concrete with Cellulose fiber, $5.59 \%$ in case of Pervious Concrete with GGBS and $16.04 \%$ in case of Pervious Concrete with both Cellulose fiber and GGBS when compared to that of Pervious Concrete with no additives at 28 days curing period.

- For Flexural strength, it was observed that there was an increment of $1.13 \%$ in case of Pervious Concrete with Cellulose fiber, $29.31 \%$ in case of Pervious Concrete with GGBS and $54.63 \%$ in case of Pervious Concrete with both Cellulose fiber and GGBS when compared to that of Pervious Concrete with no additives at 28 days curing period.

- For Coefficient of Permeability, it was observed that there was an decrement of $4.73 \%$ in case of Pervious Concrete with Cellulose fiber, $2.19 \%$ in case of Pervious Concrete with GGBS and $5.66 \%$ in case of Pervious Concrete with both Cellulose fiber and GGBS when compared to that of Pervious Concrete with no additives at 28 days curing period.

- For Modulus of Elasticity, it was observed that there was an increment of $1.7 \%$ in case of Pervious Concrete with Cellulose fiber, $53.33 \%$ in case of Pervious Concrete with GGBS and $55.55 \%$ in case of Pervious Concrete with both Cellulose fiber and GGBS when compared to that of Pervious Concrete with no additives at 28 days curing period.

- From the investigation it was observed that the Pervious Concrete mix with both Cellulose and GGBS is found out to be the best altered mix among all the considered Pervious Concrete mixes in this study. 
- From the study it was observed that there is a significant increase in the strength of Pervious Concrete when cement is partially replaced with GGBS as $30 \%$. There was also no considerable decrease in the permeability.

\section{References}

[1] Malhotra V.M "No-Fines Concrete - Its Properties and Applications", ACI Journal, Volume.73, No.11, November (1976)

[2] Meininger, R.C "No-fines pervious concrete for paving", Concrete International, August, Vol. 10, No. 8 (1988).

[3] Vinson K.D and Sargaphuti.M, Shah S.P, "Shrinkage Cracking and Durability Characteristics of Cellulose Fiber Reinforced Concrete", ACI Materials Journal (1993).

[4] Shivaji Dutta and Ghafoori.N "Building and non pavement applications of no fines concrete", Journal of Material in Civil Engineering, Vol.7, No.4, November (1995).

[5] Paul Klieger, "Further Studies on the Effect of Entrained Air on Strength and Durability of Concrete with Various Sizes of Aggregate", Vol. 25, No. 11 (2003).

[6] Amar A Muttar, "Improving the Mechanical Properties of no fines concrete", Journal of Babylon University Engineering Science, Volume-21, No.2 (2013).

[7] Darshan S Shah and Jayeskumar Pitroda "An experimental study on hardened properties of pervious concrete", Journal of International Academic Research for Multidisciplinary, Volume.2, No.3, April (2014).

[8] Swaroop.A.H.L, Venkateswararao.K, Prof Kodandaramarao.P "Durability Studies On Concrete With Fly Ash \& GGBS”, International Journal of Engineering Research and Applications, Volume.3, No.4, Jul-Aug (2013).

[9] Vinayak Awasare, Prof. M. V. Nagendra, "Analysis Of Strength Characteristics Of GGBS Concrete", International Journal of Advanced Engineering Technology, Volume 5, No.2 (2014).

[10] Huda Nema Khalifa, "Effect of Adding Cellulose as Fiber and Crystal on Some Mechanical Properties of Concrete", International Journal of Current Engineering and Technology, Volume.5, No.6, December (2015).

[11] Selvaraj. M, Amirthavarshini. M "Some Aspects of Pervious concrete", International Journal of Engineering and Applied Sciences, Volume.3, No.1, January (2016). 